
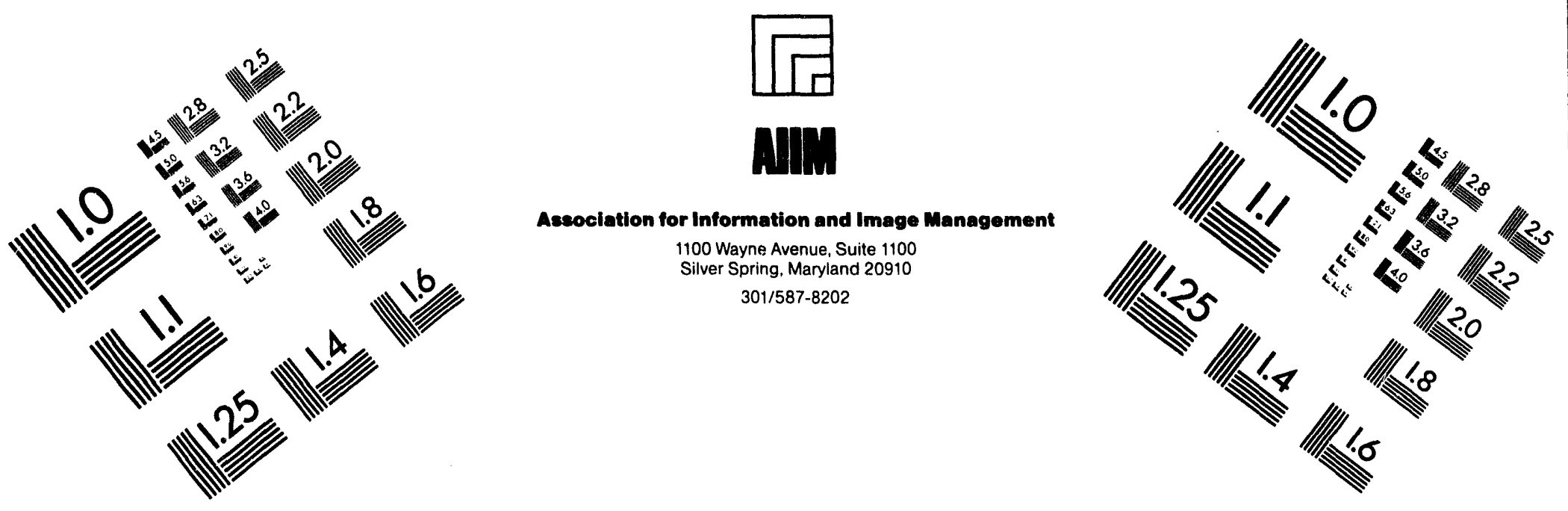

\title{
Centimeter
}

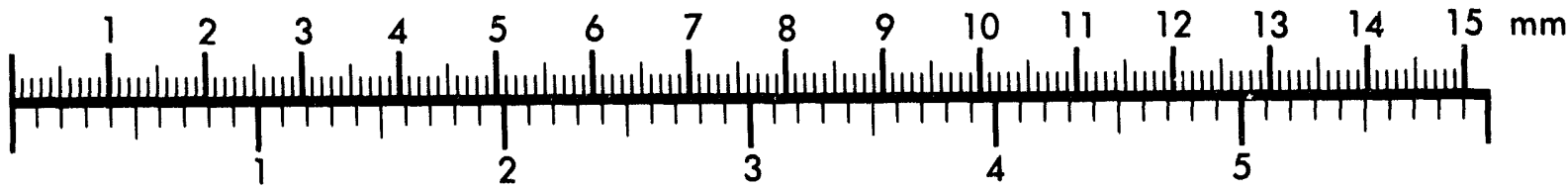
Inches
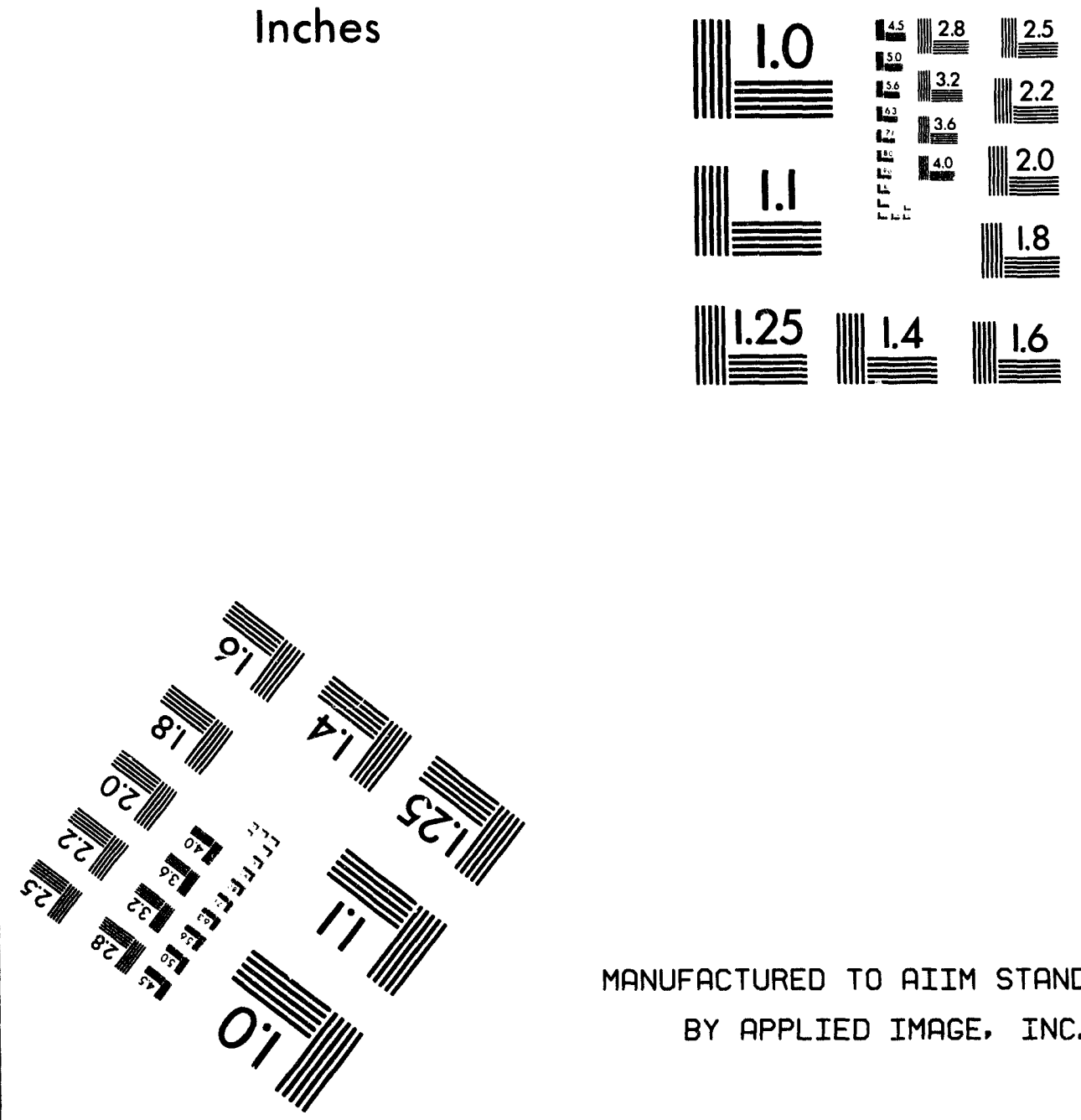

MANUFACTURED TO AIIM STANDARDS BY APPLIED IMAGE, INC.

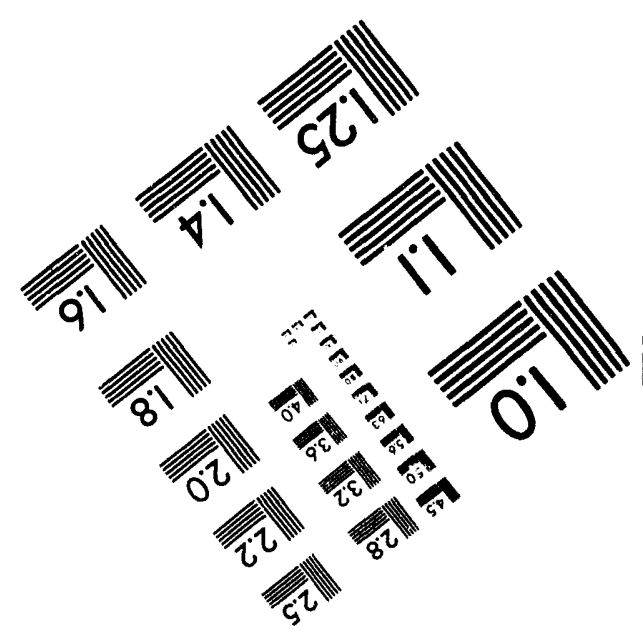



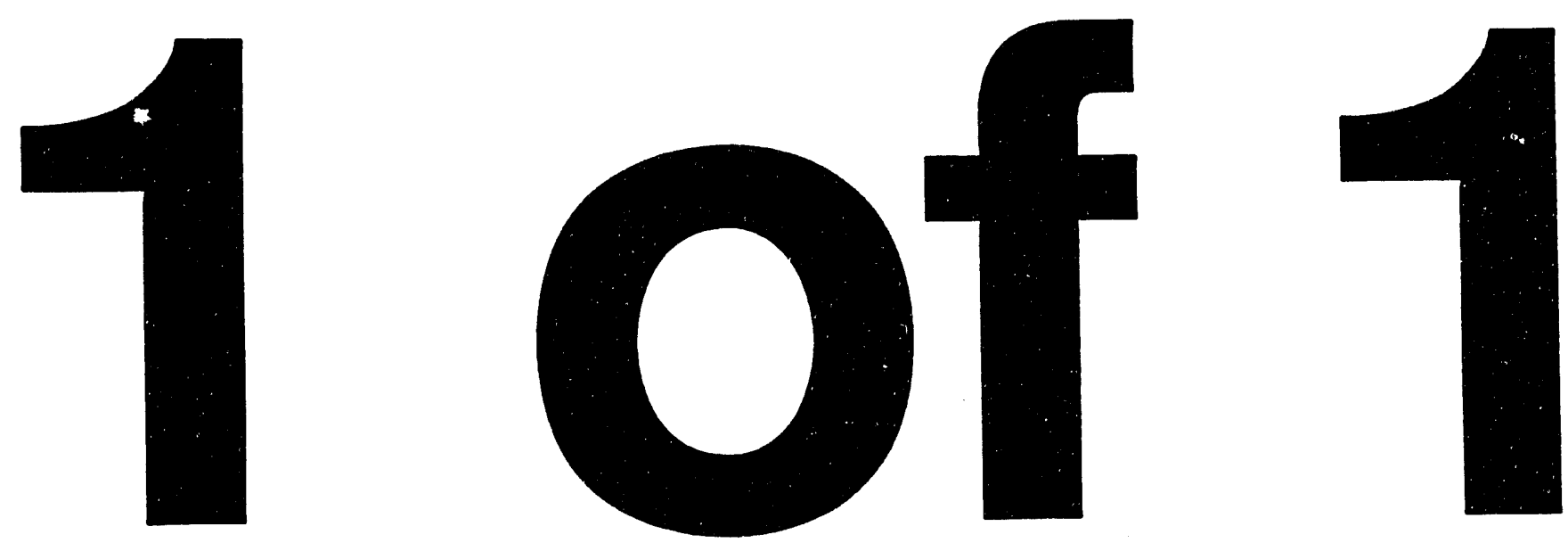


\section{Uranium Mill Tailings Remedial Action Project Waste Minimization AND Pollution Prevention Awareness Program Plan}

$$
\begin{aligned}
& \text { RECEIVED } \\
& \text { SEP } 121994 \\
& \text { OSTI }
\end{aligned}
$$

July 1994 


\section{INTENDED FOR PUBLIC RELEASE}

This report has been reproduced from the best available copy. Available in paper copy and microfiche.

Number of pages in this report: 28

DOE and DOE contractors can obtain copies of this report from:

Office of Scientific and Technical Information

P.0. Box 62

Oak Ridge, TN 37831

(615) 576-8401

This report is publicly available from:

National Technical Information Service

Department of Commerce

5285 Port Royal Road

Springfield, VA 22161

(703) 487-4650 


\section{URANIUM MILL TAILINGS REMEDIAL ACTION PROJECT WASTE MINIMIZATION AND POLLUTION PREVENTION AWARENESS PROGRAM PLAN}

July 1994

Prepared for

U.S. Department of Energy UMTRA Project Office

Albuquerque, New Mexico

Prepared by Jacobs Engineering Group Inc. Albuquerque, New Mexico

\section{DISCLAIMER}

This report was prepared as an account of work sponsored by an agency of the United States Government. Neither the United States Government nor any agency thereof, nor any of their employees, makes any warranty, express or implied, or assumes any legal liability or responsibility for the accuracy, completeness, or usefulness of any information, apparatus, product, or process disclosed, or represents that its use would not infringe privately owned rights. Reference herein to any specific commercial product, process, or service by trade name, trademark, manufacturer, or otherwise does not necessarily constitute or imply its endorsement, recommendation, or favoring by the United States Government or any agency thereof. The views and opinions of authors expressed herein do not necessarily state or reflect those of the United States Government or any agency thereof. 
TABLE OF CONTENTS

Section

Page

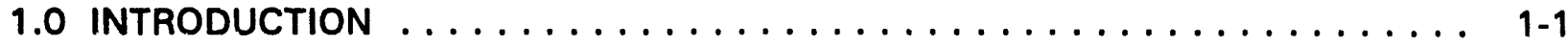

1.1 Purpose of plan .......................... 1-1

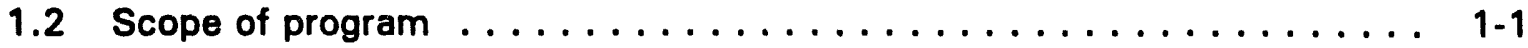

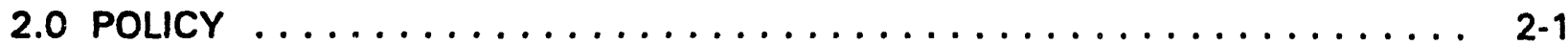

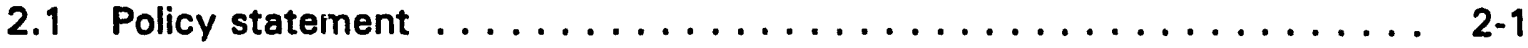

2.2 Statement of management commitment ................. 2-1

3.0 ORGANIZATION AND STAFF RESPONSIBILITIES $\ldots \ldots \ldots \ldots \ldots \ldots \ldots \ldots$

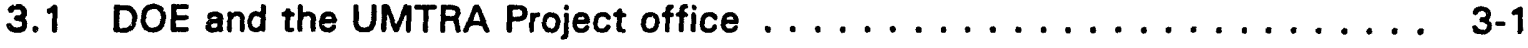

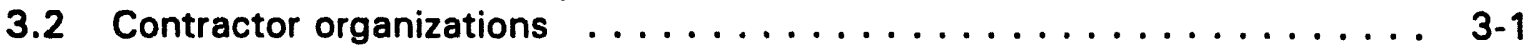

3.2.1 Remedial Action Contractor ................... 3-3

3.2.2 Technical Assistance Contractor ............... 3-3

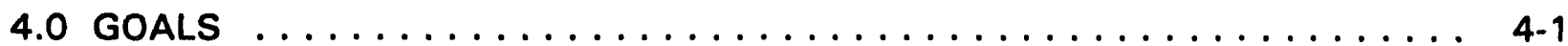

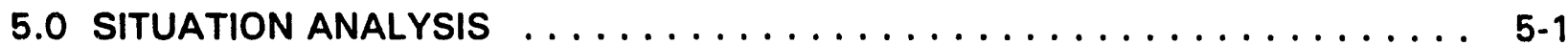

5.1 Current situation .......................... $5-1$

5.2 Program directives ....................... $5-2$

5.3 Relevant project directives or guidance $\ldots \ldots \ldots \ldots \ldots \ldots \ldots \ldots \ldots$. $\ldots \ldots \ldots$

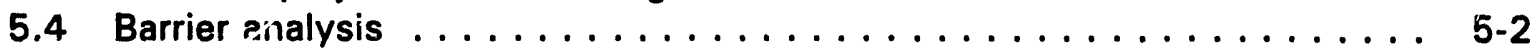

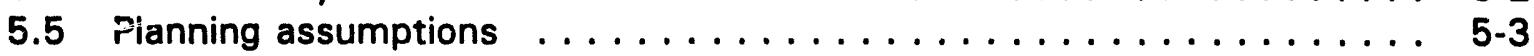

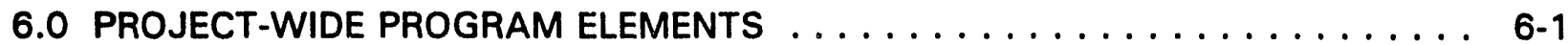

7.0 GENERATOR PROGRAM ElEMENTS $\ldots \ldots \ldots \ldots \ldots \ldots \ldots \ldots \ldots$

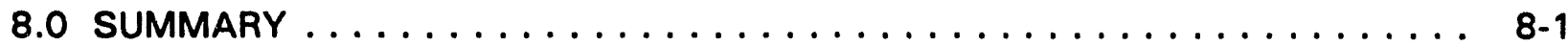

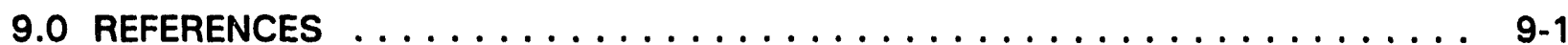




\section{LIST OF FIGURES}

Figure

Page

3.1 UMTRA Surface Project Organization $\ldots \ldots \ldots \ldots \ldots \ldots \ldots \ldots \ldots \ldots \ldots$ 


\section{LIST OF ACRONYMS AND ABBREVIATIONS}

\section{Acronym}

AL
DOE
EM
ES\&H
RAC
RRM
TAC
UMTRA
WM/PPA

\section{Definition}

DOE Albuquerque Operations Office

U.S. Department of Energy

DOE Office of Environmental Management

environment, safety, and health

Remedial Action Contractor

residual radioactive materials

Technical Assistance Contractor

Uranium Mill Tailings Remedial Action

waste minimization and pollution prevention awareness 


\subsection{INTRODUCTION}

\subsection{PURPOSE OF PLAN}

The purpose of this plan is to establish a waste minimization and pollution prevention awareness (WM/PPA) program for the U.S. Department of Energy's (DOE) Uranium Mill Tailings Remedial Action (UMTRA) Project. The program satisfies DOE requirements mandated by DOE Order 5400.1 . This plan establishes planning objectives and strategies for conserving resources and reducing the quantity and toxicity of wastes and other environmental releases.

\subsection{SCOPE OF PROGRAM}

The UMTRA Project is an environmental restoration project established by the DOE to perform remedial action at 24 inactive uranium processing sites as required by the Uranium Mill Tailings Radiation Control Act. The UMTRA Project's remedial actions involve cleanup and disposal of residual radioactive materials (RRM), (i.e., uranium mill tailings and other wastes associated with the processing sites, including contamination found at other properties in the vicinity of the mill sites). The UMTRA Project does not generate any hazardous or radioactive wastes that fit any of the waste types tracked by the DOE for its Annual Report on Waste Generation and Waste Minimization Progress (DOE, 1994a). In fact, the low-level waste definition specifically excludes uranium mill tailings.

The RRM managed at UMTRA Project sites was not generated by the DOE; it was generated decades ago when the mills were active. The UMTRA Project only "generates" the RRM by cleaning up the RRM at the former processing sites and placing it in disposal cells. Materials that become contaminated with RRM during remedial action are decontaminated when possible. Material that cannot be decontaminated or that is generated as a result of decontamination activities is disposed of as RRM. This newly generated RRM is such a minor fraction $1<0.01$ percent) of the total RRM being disposed of that its quantity is not tracked separately.

Some sanitary wastes are produced by the UMTRA Project. These wastes are primarily paper and other office trash, vehicle maintenance fluids and parts, aluminum cans, cardboard, and uncontaminated construction debris. While formal waste minimization programs are not currently required for sanitary wastes, the UMTRA Project encourages recycling when practical. Vehicle maintenance fluids and used lead-acid batteries produced at UMTRA Project sites are recycled by authorized vendors. Aluminum cans, white paper, and cardboard are recycled routinely at DOE and contractor offices in Albuquerque, New Mexico, and recycling at processing and disposal sites is performed when practical. However, due to the geographical remoteness of most sites and poor market conditions for waste paper, vendors are often not available for paper and cardboard recycling. Sanitary wastes that are not recycled are disposed of properly in off-site municipal landfills. The UMTRA Project does not track the amounts of sanitary wastes because of the cmall quantities produced. 
The primary potential sources of pollution at UMTRA Project sites are releases of RRM through surface water runoff and air emissions in the form of windborne dust. Pollution prevention strategies employed to control these releases include storm water control and dust suppression. UMTRA Project sites also implement spill prevention, control, and countermeasure plans that prevent or minimize the impact of any chemical or fuel spills that might occur. 


\subsection{POLICY}

\subsection{POLICY STATEMENT}

The UMTRA Project's environmental management policy places priority on reducing or eliminating waste through source reduction. Waste that cannot be eliminated at the source shall be recycled whenever possible using environmentally safe practices. Waste that cannot be recycled shall be disposed of using conventional methods.

The UMTRA Project shall reduce or eliminate the generation of waste through source reducrion. Whenever source reduction is not feasible, recycling using environmentally safe practices shall be considered. The use of recovered/recycled materials shall be considered when cost-effective. All waste management activities at the UMTRA Project sites shall be conducted in a manner that is consistent with applicable federal, state, and local regulations, and that minimizes risks to the environment and public health.

Worker and management awareness of waste minimization and pollution prevention philosophies shall be incorporated into daily operations. Waste minimization and pollution prevention are the responsibility of all federal and contractor employees on the UMTRA Project.

\subsection{STATEMENT OF MANAGEMENT COMMITMENT}

The DOE UMTRA Project Office and all Project particir ants are committed to minimizing waste and preventing the production of pollutants. UMTRA Project management is committed to providing adequate personnel, training, and other resources to ensure that the objectives of the UMTRA Project WM/PPA program are met. Affirmative procurement practices have been instituted to consider the use of recovered/recycled materials when feasible. 


\subsection{ORGANIZATION AND STAFF RESPONSIBILITIES}

This section presents information on the organization and management structure of the DOE Project Office and contractor organizations participating in the UMTRA Project, with a focus on WM/PPA responsibilities. Figure 3.1 shows the organizational relationships of the UMTRA Project participants.

\subsection{DOE AND THE UMTRA PROJECT OFFICE}

The DOE Office of Environmental Management (EM) has full responsibility and authority for the management, planning, and conduct of UMTRA Surface and Ground Water Project activities. The EM's programmatic responsibilities for the UMTRA Project are assigned to the Office of Southwestern Area Programs (EM-45), Offsite Program Division (EM-451).

The DOE Albuquerque Operations Office (AL) Manager has been assigned the responsibility and authority for the field management of the UMTRA Project. DOE/AL responsibilities have been assigned through the Office of Environment/Project Management to the UMTRA Project Office. The UMTRA Project Office has day-to-day responsibility for planning, coordinating, and conducting remedial actions at the uranium mill tailings sites and associated vicinity properties.

The UMTRA Project Office is organized into project controls, line management, and environment, safety, and health (ES\&H)/quality assurance policy and oversight groups. The Engineering and Construction group leader is responsible for line management of remedial actions at UMTRA Project sites, including implementation and compliance with the UMTRA Project WM/PPA program. The Technical Support group leader is responsible for ES\&H policy development and independent oversight, including defining WM/PPA program requirements and auditing for compliance. The ES\&H manager, who is in the Technical Support group, serves as the UMTRA Project Waste Minimization Coordinator. The Project Controls group leader is responsible for inanaging Project activities involving budget and schedule, including budget submittals for ES\&H-related activities such as the WM/PPA program.

\subsection{CONTRACTOR ORGANIZATIONS}

For the UMTRA Surface Project, the UMTRA Project Office is assisted by the Technical Assistance Contractor (TAC) and Remedial Action Contractor (FAC), a vicinity property Inclusion Survey Contractor, and a Grand Junction vicinity property RAC. The Grand Junction RAC, RUST Geotech, and the Inclusion Survey Contractor, Oak Ridge National Laboratory, are managed by the DOE Grand Junction Projects Office; their WM/PPA responsibilities are covered by the Grand Junction Projects Office's WM/PPA program.

The TAC is the only contract organization assisting the UMTRA Project Office with the UMTRA Ground Water Project at the present time, providing technical assistance and Project integration services. The UMTRA Ground Water RAC has yet to be determined. 


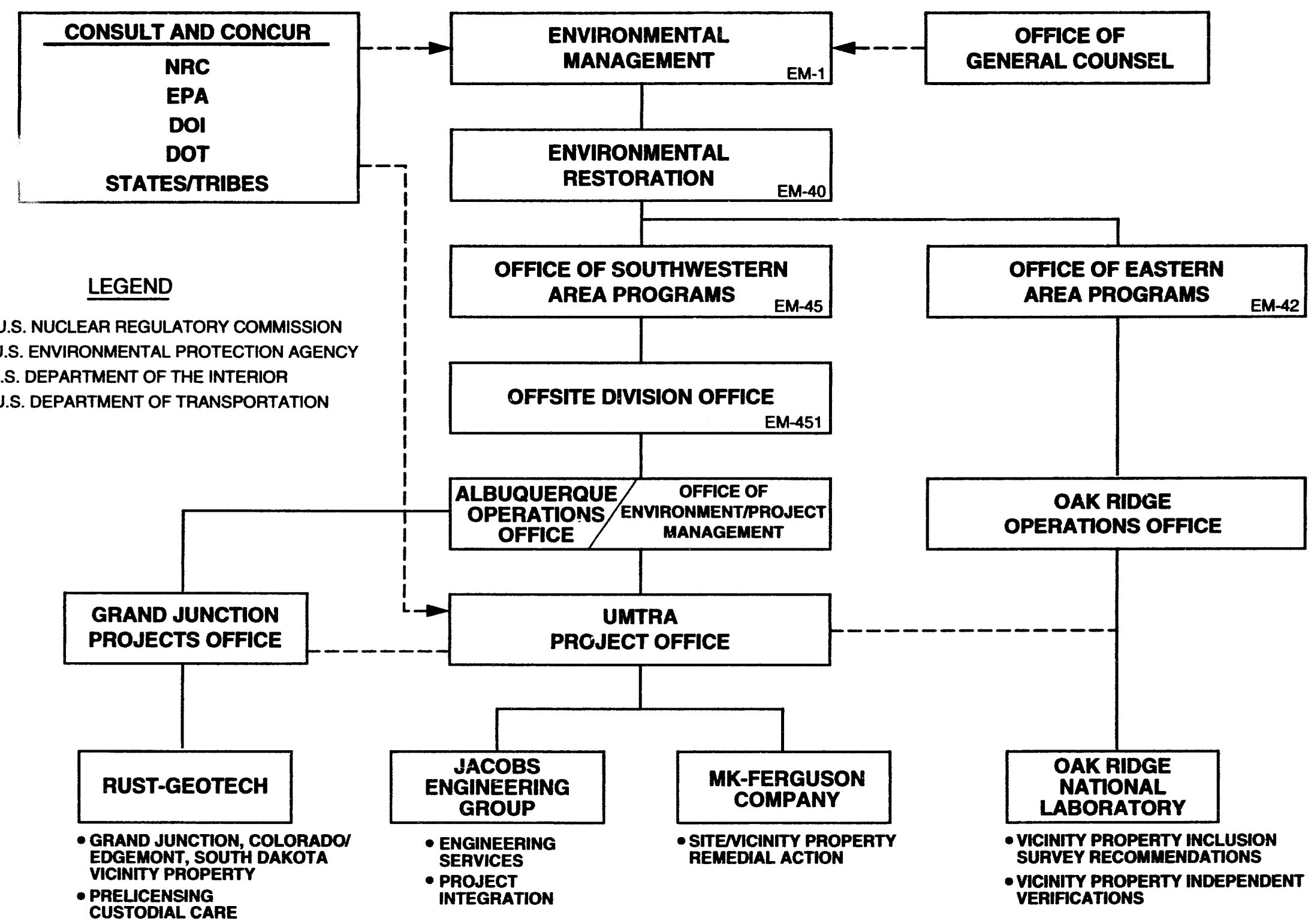

FIGURE 3.1

UMTRA SURFACE PROJECT ORGANIZATION 


\subsubsection{Remedial Action Contractor}

The UMTRA Surface RAC, MK-Ferguson Company, manages surface remedial action at UMTRA Project sites for the UMTRA Project Office. MK-Ferguson is supported by Chem-Waste Management Federal Environmental Services, Inc. and MK-Environmental Services Division. The RAC provides overall construction management services and manages the health physics programs at UMTRA Project sites. The Engineering Department has line management responsibility for implementing the UMTRA Project WM/PPA program at sites undergoing surface remedial action. The Construction ES\&H Department provides technical guidance on WM/PPA programs and oversight of site WM/PPA activities, including those of construction subcontractors.

\subsubsection{Technical Assistance Contractor}

The TAC consists of Jacobs Engineering Group Inc. and three subcontractors: Roy F. Weston, Inc., Geraghty \& Miller, Inc., and SHB AGRA. The TAC Technical Services group assists the UMTRA Project Office in developing Projectlevel programs for ES\&H, including the WM/PPA program, and in conducting compliance audits. The TAC also provides technical field support for site characterization and ground water monitoring. The TAC is responsible for implementing the UMTRA Project WM/PPA program for its activities and for assessing the RAC's compliance with the program. The TAC Regulatory Compliance Department conducts periodic environmental audits of UMTRA Project sites under the direction of the DOE ES\&H manager. These audits include assessment of site waste minimization efforts. The TAC Regulatory Oversight and Compliance Support manager supports the DOE ES\&H manager in all waste minimization coordination efforts for the Project. 


\subsection{GOALS}

Quantitative goal-setting is not readily applicable to an environmental restoration project such as the UMTRA Project. However, the UMTRA Project has established the following qualitative WM/PPA goals:

- Eliminate the generation of hazardous waste.

- Minimize the generation of waste contaminated with RRM.

- Maintain releases of pollutants to below discharge limits.

- Reduce the generation of nonhazardous solid wastes.

- Recycle waste materials whenever possible.

- Procure recovered/recycled materials whenever feasible. 


\subsection{SITUATION ANALYSIS}

\subsection{CURRENT SITUATION}

During 1992, the UMTRA Project developed a programmatic WM/PPA program that includes activities to eliminate or minimize the generation of radioactive, hazardous, and other solid wastes. This program was implemented in a cost-effective manner using a graded approach to determine an appropriate scope for the program. In addition, the UMTRA Project has implemented site-specific WM/PPA programs to identify, prevent, minimize, and manage wastes at UMTRA Surface Project remedial action sites.

At UMTRA Surface Project sites, waste minimization begins with the development and implementation of subcontract specifications and the RAC WM/PPA program (MK-F, 1992). These documents outline specific waste minimization requirements that must be implemented by subcontractors and approved by RAC project management. Site-specific plans are developed identifying the necessary waste management activities to ensure that all elements of the WM/PPA program are implemented. These WM/PPA elements include the following:

- Identification of site-specific wastes and waste streams.

- Development of spill prevention, control, and countermeasure plans.

- Development of contamination prevention procedures for equipment and materials.

- Review of waste handling and disposal methods.

- Evaluation of waste reuse and recycling options.

- Control of chemicals used on-site.

Site workers are trained in good housekeeping practices and decontamination procedures. Following these practices and procedures indirectly minimizes or avoids the generation of waste by reducing spillage and preventing the spread of contamination.

DOE, RAC, and TAC employees have the opportunity to submit suggestions for any ideas that reduce waste, improve environmental awareness, or conduct UMTRA Project operations in a more efficient and environmentally sound manner. WM/PPA suggestions are specifically solicited. For suggestions that are implemented, the employee receives a certificate of recognition and is invited to attend an annual luncheon.

The UMTRA Project offices in Albuquerque also have programs to recycle office waste. White paper recycling boxes have been placed in DOE, RAC, and TAC offices. Aluminum cans are collected for recycling to raise funds for local schools and charitable organizations. Used computer paper is also donated to a local school 
for reuse by students. These programs are publicized internally to make employees aware of the benefits of their recycling/reuse efforts.

Due to the lack of large-scale waste minimization opportunities on the UMTRA Project, tracking and reporting systems are not cost-effective and are not in place.

\subsection{PROGRAM DIRECTIVES}

The UMTRA Project has considered the following statutes and directives to identify regulatory drivers for the UMTRA Project WM/PPA program:

- DOE Order 5400.1.

- DOE Order 5820.2A.

- Resource Conservation and Recovery Act.

- Executive Order 12843.

- Executive Order 12856.

- Executive Order 12873.

\subsection{RELEVANT PROJECT DIRECTIVES OR GUIDANCE}

The UMTRA Project fully endorses and adopts the WM/PPA goals identified in the DOE/AL "Environmental Policy Statement" (DOE, 1992a). The UMTRA Project's commitment to WM/PPA is clearly stated in its "ES\&H Goal Statement" (DOE, 1992b) and Environmental Protection Implementation Plan (DOE, 1993a).

The RAC has established a WM/PPA program that forms the basis for site-specific programs at surface remedial action sites (MK-F, 1992).

\subsection{BARRIER ANALYSIS}

There are three primary barriers to implementing a more formal WM/PPA program for the UMTRA Project:

- UMTRA Project sites are widely scattered (24 sites in 10 states) and are generally located in remote areas with low population densities. The distance from large popilation centers makes it difficult to find cost-effective recycling options for some waste types.

- UMTRA Project construction subcontractors vary from site to site. Many subtier contractors are small, local companies, and the UMTRA Surface Project RAC has little control over their procurement practices. The lack of a single maintenance- and operations-type contractor such as found at centralized DOE sites prevents cost-effective implementation of formal waste tracking and affirmative procurement programs. 
- Surface remedial actions at UMTRA Project sites are generally of short duration (1 to 3 years) and do not result in the generation of any process wastes. In addition, the UMTRA Surface Project will end shortly, with most surface remedial actions expected to be completed during fiscal year 1996. The nature of site-specific activities and the short Project life left make it difficult to justify a more formal WM/PPA program.

\subsection{PLANNING ASSUIMPTIONS}

The WM/PPA program described in this plan is based on the following assumptions:

- The UMTRA Project mission will not change.

- Hazardous and toxic wastes will not be generated as a result of surface remedial actions or ground water remediation activities.

- Formal WM/PPA programs for sanitary wastes are not necessary and will not be made mandatory. 


\subsection{PROJECT-WIDE PROGRAM ELEMENTS}

Executive Order 12856, the UMTRA Project ES\&H Management Plan for Fiscal Years 1996-2000 (DOE, 1994b), DOE Defense Programs' Pollution Prevention Program Strategic Plan (DOE, 1993b), and the 1993 Waste Minimization/Pollution Prevention Crosscut Plan (DOE, 1993c) all require discrete budgeting for WM/PPA. However, the UMTRA Project does not request funding specifically for implementation of its WM/PPA program.

Since the UMTRA Project does not routinely generate any of the waste types typically tracked by the DOE, the UMTRA Project has determined that it is not cost-effective to implement formal programs that can be discretely budgeted. Therefore, the WM/PPA program described in this plan is implemented and funded as part of the UMTRA Project's overall ES\&H program. Since the UMTRA Project does not have any detailed budget estimates for its WM/PPA program, no resource requirements are identified in this plan. 


\subsection{GENERATOR PROGRAM ELEMENTS}

For the reasons identified in Section 6.0, the UMTRA Project has not directed its contractors to develop formal WM/PPA programs that can be discretely budgeted. Contractors incorporate the principles of WM/PPA into their overall ES\&H programs. Therefore, UMTRA Project contractors do not have detailed budget estimates for their WM/PPA programs, and no generator resource requirements are identified in this plan. 


\subsection{SUMMARY}

While uranium mill tailings and other RRM being cleaned up by the UMTRA Project are not addressed by the UMTRA WM/PPA program, other wastes generated from Project activities are addressed. The only waste type the UMTRA Project generates that fits the waste type description tracked by the DOE is sanitary waste. The UMTRA Project does not have formal WM/PPA programs in place because they are not cost-effective given the nature and limited life of the Project. However, the UMTRA Project Office encourages its contractors to follow WM/PPA principles when feasible. Project participants currently recycle a variety of waste materials. Because of the informality of its WM/PPA program, the UMTRA Project does not request funding specifically for its implementation. Instead, WM/PPA is integrated into the Project's overall ES\&H Program. 


\subsection{REFERENCES}

DOE (U.S. Department of En'rgy), 1994a. Annual Report on Waste Generation and Waste Minimization Progress 1991-1992, Office of the Secretary, Washington, D.C.

DOE (U.S. Department of Energy), 1994b. ES\&H Management Plan for Fiscal Years 19962000, UMTRA Project Office, Albuquerque, New Mexico.

DOE (U.S. Department of Energy), 1993a. Uranium Mill Tailings Remedial Action Project Environmental Protection Implementation Plan, DOE/AL/62350-79, October 1993, prepared by the U.S. Department of Energy, UMTRA Project Office, Albuquerque Operations Office, Albuquerque, New Mexico.

DOE (U.S. Department of Energy), 1993b. Pollution Prevention Program Strategic Plan, Assistant Secretary for Defense Programs, Washington, D.C.

DOE (U.S. Department of Energy), 1993c. 1993 Waste Minimization/Pollution Prevention Crosscut Plan, Office of the Secretary, Washington, D.C.

DOE (U.S. Department of Energy), 1992a. "Albuquerque Operations Office Environmental Policy Statement," October 28, 1992, Albuquerque Operations Office, Albuquerque, New Mexico.

DOE (U.S. Department of Energy), 1992b. "UMTRA Project Environmental, Safety, and Health Goal Statement," May 1992, UMTRA Project Office, Albuquerque, New Mexico.

DOE (U.S. Department of Energy), 1992c. Waste Minimization Crosscut Plan Implementation, Secretary of Energy Notice SEN-37-92, Office of the Secretary, Washington, D.C.

DOE (U.S. Department of Energy), 1993a. UMTRA Project Environmental Protection Implementation Plan, DOE/AL/62350-79, UMTRA Project Office, Albuquerque, New Mexico.

MK-F (MK-Ferguson Company), 1992. Waste Minimization and Pollution Prevention Program for the UMTRA Project, prepared by MK-Ferguson, Albuquerque, New Mexico, for the U.S. Department of Energy, UMTRA Project Office, Albuquerque, New Mexico.

\section{DOE ORDERS}

Order 5400.1, General Environmental Protection Program, November 8, 1988, U.S. Department of Energy, Washington, D.C.

Order 5820.2A, Radioactive Waste Management, September 26, 1988, U.S. Department of Energy, Washington, D.C. 


\section{EXECUTIVE ORDERS}

Executive Order 12843, Procurement Requirements and Policies for Federal Agencies for Ozone-Depleting Substances, April 21, 1993, Office of the President, Washington, D.C.

Executive Order 12856, Federal Compliance with Right-to-Know Laws and Pollution Prevention Requirements, August 3, 1993, Office of the President, Washington, D.C.

Executive Order 12873, Federal Acquisition, Recycling, and Waste Prevention, October 21, 1993, Office of the President, Washington, D.C.

\section{UNITED STATES CODE}

42 USC $\$ 6901$ et seq., Resource Conservation and Recovery Act, October 21, 1976.

42 USC $\$ 7922$ et seq., Uranium Mill Tailings Radiation Control Act, November 8, 1978. 

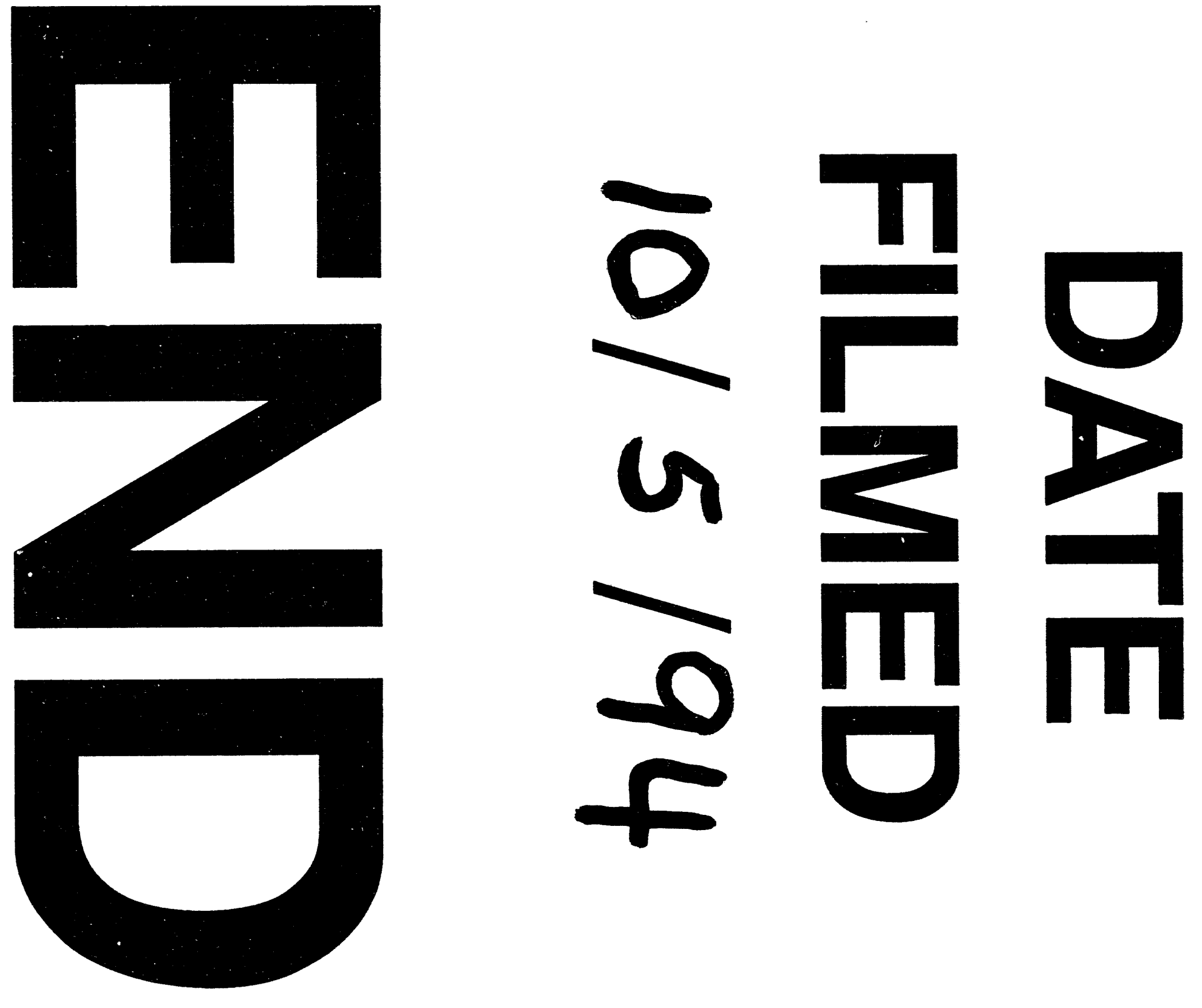


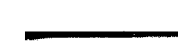

